\section{The challenges of waste management to Nigeria sustainable development: A study of Enugu State}

Faculty of Management Sciences, Nnamdi Azikiwe University, Awka, Nigeria (ee.chukwuemeka@unizik.edu.ng) Osisioma, B. C.

Department of Accountancy, Nnamdi Azikiwe University, Awka, Nigeria (benosisioma@yahoo.com)

Onwuka, Ebele

Department of Business Administration, Nnamdi Azikiwe University, Awka, Nigeria (ebeleonwuka@yahoo.co.uk)

Ugwu, Joy

School of Business Studies, Institute of Management and Technology,Enugu, Nigeria (nonnyjoy@yahoo.com)

Received: 3 June 2012

Available Online: 28 June 2012
Revised: 20 June 2012 DOI: $10.5861 /$ ijrsm.2012.141

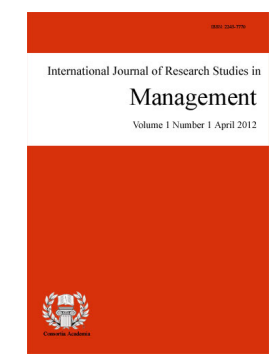

ISSN: $2243-7770$ Online ISSN: 2243-7789

OPEN ACCESS

\title{
Abstract
}

The problem of solid waste management has become a debilitating factor towards sustainable development in Nigeria. The study therefore was carried out to evaluate the chains of problems militating against solid waste management in Nigeria with particular stress on Enugu State. The study adopted survey research method. Data collected through questionnaire were analyzed and hypotheses tested using Z-test statistical measure. The scientific investigation revealed among other things that resources normally voted by Government year by year to manage solid waste is always very meager. There is no environmental education at all as was observed during the field investigation. Furthermore, some of the waste management staff were poorly trained and no plan in the future to give them further training or to improve already acquired skill. Based on the findings, some of the major recommendations are that solid waste management should be provided with a separate head in the budget for the purpose of adequate revenue allocation, implementation and monitoring. The participation of the local communities in solid waste management should be encouraged. Environmental education should be intensified by both the state and local government. Also primary, secondary and tertiary schools curricula should inculcate detailed topics on solid waste management.

Keywords: sustainable development; environment; government; management; waste 


\section{The challenges of waste management to Nigeria sustainable development: A study of Enugu State}

\section{Introduction}

The environment of man lies at the mercy of both natural disaster and negligence on the part of man in the course of controlling the gifts of nature. The later, takes the form of dumping solid/ industrial waste in an uncompromising, desert encroachment, erosion, depletion of ozone layer, depletion of natural resources, pollution of land, rivers, seas the air and generally the environment. In early times (pre-colonial days up till 1970s, the disposal of refuse and other wastes did not pose any significant problem. The population was small and enough land was available for assimilation of wastes. Solid waste problem started with urban growth resulted partly from national increase in population and more importantly from immigration (Egunjobi, 1986). No towns in Nigeria especially the urban and semi-urban centers of high population density can boast of having found a lasting solution to the problem of filth and huge piles of solid waste, rather the problem continues to assume monstrous dimensions (Okpala, 1986). To urban and city dwellers, public hygiene starts and ends in their immediate surrounding and indeed the city would take care of itself. The situation has so deteriorated that today the problem of solid waste has become one of the nation's most serious environmental problem.

Problem with the disposal of solid waste in Enugu State of Nigeria especially in Enugu Urban could be traced to the period of the military rule. When the Military took over leadership in 1984, it established a full-fledged Agency called Anambra State Environmental Sanitation Agency to deal with the problem of solid waste. This is to show the importance of solid waste management to ensure the good health of the citizenry. In a survey conducted in 15 Nigerian towns in March 2002, a total of 600 people were asked to define precisely what they understand as 'waste', definitions received include 'unwanted materials' (8\%), useless object (20\%), garbage (22\%), rubbish (7\%), dirt (15\%), refuse (28\%) (Nwokocha, 2012). According to Udechukwu (2009), wastes are useless, unwanted and discarded materials' Douglas (2004) corroborates Udechukwu's stance and argues that 'waste is material which arises from animal and human life and activities and is discarded as useless and unwanted. Number 16 of Lagos State Environmental Sanitation Law of 1984 defines 'domestic waste' 'refuses' and section 27 defines waste as:

waste of all descriptions,

$>\quad$ any substances which constitute scrap material or an efficient or other unwanted,

$>\quad$ surplus substances arising from application of an process, and

$>\quad$ any substance or article which requires to be disposed of as broken, worn out or otherwise spent.

The United States Environmental Protection Agency defines solid waste as any useless, unwanted or discarded material with insufficient liquid content to be free flowing. While, the need for healthy environment is important to everybody; it may differ from place to place, not in the fundamentals but in complexity (Laoye, 1979).

\subsection{Statement of problem}

Inadequate solid waste management which was relatively bearable in Enugu State, especially in Enugu Urban before 1980, became impossible now especially with the growing of urbanization, rural urban migration and sitting of buildings and other infrastructures in areas designated as solid waste disposal points. Furthermore the proliferation of public and private schools, hospitals and eating houses generate more than ninety-five (95\%) of the refuse especially in Enugu Urban centre (Eze, 2008).

Problem with the disposal of solid waste in Enugu State could be traced to late 70s when rural poverty increased which caused high rural-urban migration. Rapid urban growth in Nigeria accompanied by increasing 
The challenges of waste management to Nigeria sustainable development: A study of Enugu State

population, traffic-congestion, air and waste, pollution, capital production of solid waste and non availability of places designated for waste disposal. In the absence of a regular and efficient solid waste collection system, waste is dumped in open spaces, on access roads and along water courses, which constitutes health hazard.

In most parts of Enugu urban, there are no public facilities for disposing refuse within reasonable distance. Dump sites or waste bins are non-existent and where dumps are sited overflow with refuse, constituting health/fire hazards. However, the Government of Enugu State of Nigeria adopted different methods of solid waste disposal. One time, the incinerator machines were used and recently solid waste conversion vehicles are used and yet solid waste still constitute a major health hazard in the Enugu Urban. It is believed that the refuse disposal vehicles are inadequate. The areas that are more susceptible to the endemic problem are Abakpanike, Obiagu, Uwani, and Achara layout zones. Some people who were arraigned in the Environmental Court on waste disposal related offences oftentimes claimed that they were not properly sensitized or educated on how to dispose or manage their solid waste.

The Enugu State Waste Management Agency has been indicted by many citizens and groups as not doing their work well. This resulted to frequent change of leadership of the Agency. In spite of the frequent change in leadership of ESWAMA the problem of solid waste and its attendant health and fire hazard is still there. There is no gainsaying that problem resulting from poor solid waste management has retard the development of Enugu State in particular and Nigeria at large.

\subsection{Objectives of the Study}

The objectives of this study are:

A. To assess the effectiveness of the Enugu State Waste Management Agency in the handling of solid waste management

B. To find out whether the people of Enugu State are properly educated on environmental matters

C. To proffer solutions to the problems identified

\subsection{Hypotheses}

A. The Enugu State Waste Management Agency faces the challenge of inadequate disposal vehicles and that is impeding on their efficient service delivery

B. Many people in Enugu State are yet to receive proper environmental education

\section{Literature Review}

Graiser (2007) refers to solid waste as 'solid material which is discarded. This definition ignores the relevant issue of the usefulness, value, or desirability of the matter in question, but in as much as discarding is an intentional act, it implies that the discarded judges the material to be of relatively little current value to him. Rodgers, (2011) contends that waste management is a systematic control of generation, storage, collection, transportation, separation, processing, recovery and disposal of solid waste. In the smallest of places, solid waste management is accepted as a major aspect of the indigenous community organization and traditional home management; hence every house/compound has a designed area for solid waste collection/disposal and or incineration (Sanda, 2008). In Nigeria, wastes are generated in homes, commercial, industrial sites, hospitals, schools, on streets and even religious activities.

\subsection{Solid Waste Management - etymological discourse}

Ezema (2009) argues that the amount of waste generated by human population was very insignificant. This 
was due to the size of the population and the spread of population around the world, coupled with the fact that there was very little exploitation of natural resources. Common wastes produced during the early ages were mainly ashes and human wastes; these were released back into the ground, which did not cause any harm to the environment. Before the invention of metals, wood was widely used for most application. However, the reuse of wood has been well documented. Best example being the reuse of timbers for shipbuilding purposes. With the invention of metals viz: bronze and iron, their use became common in most applications. Nevertheless, it is once again well documented that reuse and recovery of such metals have been carried out by early humans.

With the advent of industrial revolution, waste management became a critical issue. This is owing to the increase in population and massive shifts in population from rural areas to industrial towns and cities during mid 18th century. There was a consequent increase in industrial and domestic wastes posing threat to human health and environment. By mid 19th century, considerable efforts had begun towards managing wastes. Incinerators were first used during late 19th century in United Kingdom, but they were opposed on the grounds of emissions, which fell unto the surrounding residential areas. Further to this a series of legislations were passed in response to concern over human health and environment (Johnson, 2009).

In United States, the Environmental Protection Agency (EPA) is the national agency that works to protect human and the natural environment. Environmental Protection Agency (EPA) established and enforces national environmental protection standards, conducts research on environmental problems, and assists other organizations in protecting the environment through grants, technical assistance and other programmes.

The following descriptions introduce and define the main activities classifies under Integrated Solid Waste Management (ISWM). Waste prevention: Waste prevention often called source reduction means reducing waste by not producing it. Example of waste prevention would include purchasing durable, long lasting goods and seeking products and packaging that are as face of toxic substances as possible. It can be as simple as switching from disposal to reusable products, or as complex as redesigning from a product to use fewer raw materials or last longer.

Recycling: recycling makes use of materials that otherwise would become waste by turning them into valuable resources. Recycling helps reduce green house gas emission, in part, by diverting waste from landfills, In some countries, a great deal of recycling occurs before the waste reaches the landfill. Scrap dealers by directly from households and business, waste pickers of scavengers collect material from waste bin, and waste collectors separate materials that can be sold as they load their truck.

Composting: Another form of recycling according to Uche (2010) is composting the controlled aerobic biological decomposition of organic matter such as food scraps and plant matter into humus, a soil-like material compost acts as a natural fertilizer by providing nutrients to the soil, increasing beneficial solid organisms and suppressing certain plant diseases thereby reducing the need for chemical fertilizers and pesticides in land scraping and agricultural activities. Organic material often comprises a large portion of the solid waste stream, particularly in communities that rely heavily on tourism. Composting can be particularly, helpful to communities managing their waste and thus reducing their waste and thus reducing greenhouse gas emissions.

Combustion: Combustion is the controlled burnings of waste in a designated facility to reduce its volume and in some cases, to generate electricity. Combustion is an I.S.W.M. option for waste that cannot recycle or composted argues Tim (2008), and is sometimes selected by communities where landfill space is limited. While the combustion process can generate toxic air emission, installing control equipment such as acid gas scrubbers and fabric filters in combustors. Combustion of solid can help reduce amount of waste going to landfills. They also can reduce reliance on coal, one of the fossil fuels that produces green houses goes when burned.

\subsection{The Need for Environmental Education, awareness and public participation}

Environmental education is necessary for improving environmental quality (Emeribe,2000). Much of 
The challenges of waste management to Nigeria sustainable development: A study of Enugu State

traditional solid waste management practices such as waste burning, indiscriminate open dumping of waste, ecological ideals and government regulations often arouse conflict. Enlightened debates, public awareness and even outright opposition can promote a forum for dialogue and conflict resolution which can lead to balanced policies which will enhance public commitment. Such a system that involves people's participation is democratic. A better understanding of solid waste management and its attendant problems will enhance the effective use of the environment. Although people are capable of influencing their environment in both constructive and destructive ways, yet, much of the influence has been in the service of making the environment less attractive. People are depleting natural resource and polluting the environment at an alarming rate and it is, therefore, important to educate people better in order for them to have positive attitude, commitment, and motivation to adopt sound techniques in managing their waste products.

Environmental education and awareness among decision makers will accord with Emeribe (2000) considerably help in a better integration of environmental issues into development planning, budgeting and policy formulations. This will be reflected in the attitude and actions of government functionaries (Aina and Salam, 1992). Furthermore, the Nigerian populace, both in urban and rural areas, no matter their socio-economic status, need to be sensitized to solid waste management issues and problems. Without proper education, orientation and public awareness at all levels of society; it will be difficult to manage solid waste. Thus, environmental education among the people would generate environmental concerns which could lead to the formation of groups concerned with how to protect the potentials of the environment and avoid or minimize the hazards of environmental pollution and degradation -.for instance, environmental groups in the more advanced countries like the Green Peace, the Friends of the Earth, the Sierra Club, and many others, have fought great battles to preserve and protect various species of plants and animals (Agukoronye, 1994). Finally, and very importantly, environmental education and public participation in the long run can be cost-saving as expected attitude and commitment to the environment change for better, Hazards of pollution would not only be minimized but the cost of control will also reduce.

\subsection{Solid Waste management for Sustainable Development}

Sustainable development is most often defined as 'development that meets the needs of the present without compromising the ability of future generations to meet their own needs' (Emeribe, 2000). Although sustainable development means different things to environmental planners, ecologists, economists and environmental activists, it is important to recognize that, the fulfillment of human needs also depends on environmental factors such as availability of pure water, clean air, adequate living space, and in many circumstances, people's ability to maintain a spiritual, cultural and aesthetic relation with their environment. This calls for management of the environment as it affects solid waste management. If solid waste disposal is not managed properly it affects underground water, affect the aesthetic condition of our environment and causes health hazards.

Again, before sustainable development can be achieved, a clear understanding of its political economy will be necessary. But in Nigeria, it has been found that there are no clearly formulated policies aimed at coordinating and monitoring the relationship between environment and economic development. Rather, there are a number of poorly articulated programmes, rules and legislations which when reviewed and analyzed may help to reveal the directions as well as the limitations of environmental and natural resource management (Dharam \& Vivian, 1995). Thus, the goal of sustained development and healthy economic growth inherently requires careful attention to the environment which includes proper management of solid waste.

\section{Methodology}

\subsection{Research design}

The survey was used to gather data on the basis of its usability with large samples as was the case with the present study where $\mathrm{N}=450$. The study is largely interpretive because it focuses on qualitative and quantitative 
data.

\subsection{Sample}

Four hundred and fifty respondents formed the sample for the study. The implication is that the entire population was studied because the number is manageable. The sample had diversity in terms of age, sex, social economic status, and experience among other variables.

\subsection{Instrumentation}

Questionnaire items were used to source data from the respondents. The items sought to which the respondents understood the problem of solid waste management in Nigeria as they were conceptualized in the literature review. The questionnaire was pilot tested and rated highly by raters with extensive experience in the use of the instrument for research purposes. The ease of access to the respondents by the researcher, allowed for a personal administration of the instrument which ensured eighty nine percent return rates thereby eliminating non-return bias. In-depth interviews were conducted with 200 respondents who are staff of Enugu State Waste Management Agency as a follow-up to the questionnaire in order to glean the subtle aspects that questionnaire items could not adequately elicit. Interviews focused mainly on the respondents' justifications for particular response options to questionnaire items.

\section{Data presentation and Analysis}

Responses that were relevant to the objectives and hypotheses formulated were used. The method applied in the analysis was difference in proportion, and, in testing the hypotheses formulated, Z-test was used.

\subsection{Analysis of data and test of hypotheses}

\section{Hypothesis 1}

The Enugu State Waste Management Agency faces the challenge of inadequate waste disposal vehicles and that is impeding on their efficient service delivery.

\section{Table 1}

The Government has not provided enough waste disposal vehicles because of lack of interest in championing a clean environment

\begin{tabular}{|c|c|c|c|}
\hline $\mathrm{S} / \mathrm{N}$ & Options & Frequency & Percentage $(\%)$ \\
\hline 1 & Strongly Agree & 150 & 37.50 \\
\hline 2 & Agree & 100 & 25.00 \\
\hline 3 & Undecided & 70 & 17.50 \\
\hline 4 & Disagree & 50 & 12.50 \\
\hline 5 & Strongly disagree & 30 & 7.50 \\
\hline Total & & 400 & 100.00 \\
\hline
\end{tabular}

Decision: Since our computed "Z" value of 0.024 falls between -1.96 and 1.96 of our critical value, the researcher reject the null hypothesis, since the researcher rejected the null hypothesis; the researcher therefore accept the alternative hypothesis which states that the Enugu State Waste Management Agency faces the challenge of inadequate disposal vehicle which impedes the efficient discharge of their services.

\section{Hypothesis 2}

Many people in Enugu State are yet to receive proper environmental education.

Decision: Since our computed "Z" value of 0.024 falls between -1.96 and 1.96 of our critical value, the 
The challenges of waste management to Nigeria sustainable development: A study of Enugu State

researcher reject the null hypothesis, since the researcher rejected the null hypothesis, the researcher therefore accept the alternative hypothesis which states that many people in Enugu State are yet to receive proper environmental education.

\section{Table 2}

The level of environmental education by the state and local government is poor

\begin{tabular}{llcc}
\hline & \multicolumn{1}{c}{ Options } & Frequency & Percentage $(\%)$ \\
\hline 1 & Strongly Agree & 155 & 38.75 \\
2 & Agree & 100 & 25.00 \\
3 & Undecided & 40 & 10.00 \\
4 & Disagree & 50 & 12.50 \\
5 & Strongly disagree & 55 & 13.75 \\
Total & & 400 & 100.00 \\
\hline
\end{tabular}

\section{Discussion of Findings}

The outcome of data analysis and information obtained from literature review the researcher discovered the following that:

$>\quad$ The resources available for solid waste management are much less to make any impact. This has made it hard for the procurement of sufficient pay loaders, bulldozers, tippers, din chassis, compactors, incinerators, waste bins, refuse vans etc.

$>$ Those interviewed favored public planning participation (contractors) to assist in refuse collection, treatment and disposal. Many also favored public private participation.

$>\quad$ More than $69 \%$ of the respondents knew nothing about procurement of dustbins, dumpsites. They do not also know the organs of government that are responsible for refuse/waste management.

$>\quad$ There is some legislation for refuse/waste management, either due to lack of manpower or any other reason the laws were not used or are rarely used.

$>$ There is no environmental education at all as was observed during the administration of the questionnaire.

$>$ Burning of waste was the order of the day with the attendant hazards associated with it.

$>\quad$ Some of the waste management staff was poorly trained and no plan in the future to give them further training or improved the already acquired skills.

\section{Management implications for the findings}

Poor solid waste management in Nigeria has many implications and challenges for management. The Agency of Enugu State Government that is charged with solid waste management suffers from acute shortage of skilled manpower and purposeful leadership. The little skilled manpower in the Agency argues Uzoamaka (2010) are not adequately motivated to challenge them to put in their best. Most of the public managers who ran the Agency were employed by executive fiat. Many of them lacked personal motivation and therefore could not motivate their employees. It is also evident that human capital development in Enugu State Waste Management Agency is very low. The Government in their yearly budget scarcely allocates sufficient funds in the area of staff training. Management decision making is another important area of management that ought to be properly considered but was awfully neglected.

\subsection{Recommendation}


A. Solid waste management should be provided in the yearly budget with a separate head for the purpose of adequate revenue allocation, implementation and monitoring.

B. There is need to enhance environmental education programmes and public participation as it affects solid waste management not only through the radio, television and print media but also through grassroots enlightenment campaigns via the chiefs, community leaders.

A. Effective solid waste management requires the involvement, participation and cooperation of local communities and the government.

B. Public private partnership is highly encouraged in solid waste and environmental management.

C. Government should commit itself to sponsoring more research projects into the reduction of solid waste at source, collection and efficient disposal.

D. Primary, secondary and tertiary schools curricula should inculcate detailed topics on solid waste management.

E. There should be adequate and proper town planning for effective solid waste management for example, there is a need to provide good access, roads, which should be properly linked to one another. Other needs are streetlights and good drainage system. All these will ease the evacuation of solid waste from all the nooks and crannies of the state.

F. There should be comprehensive environmental legislation that relates to environmental sanitation offences. The cases should be tried in environmental courts.

\subsection{Conclusion}

To achieve a sustainable development in Nigeria, it requires efficient management of solid waste. There is need to adopt a more efficient approach to preventive environmental education. Environmental education and public participation option lead to an increasing awareness that environmental precautions are important for continued socio-economic development in the long run. A degraded environment cannot sustain a continued growth and it impacts negatively on the entire development of a nation.

\section{References:}

Agukoronye, O. C. (1994, October). Environmental education and public participation in environmental management. Paper presented in a symposium on Environmental and Social harmony, Enugu State University.

Aina,T. A., \& Salan, A. T. (Eds.) (1992). The challenge of sustainable development in Nigeria. Ibadan: Intec Printers, Ltd.

Bridgewater, A. K. (1980). Waste management in Europe. England: Van Stand Reinhold Co. Ltd.

Dharam, G., \& Vivian, J. M. (Eds.) (1995). Grassroot environmental action: People's participation in sustainable development. London: Routledge.

Douglas, S. E. (2004). The politics of Nigeria underdevelopment. Journal of Policy and Development Studies, l(2) 34-39.

Eguniobi, E. (1996). Fundamentals of urban administration in Nigeria. Enugu: HRV Publishers.

Emeribe, A. C. (2000). Environment, solid waste management for sustainable development in Nigeria: Some new perspectives, policy and contending issues in Nigerian national development strategy. Enugu: John Jacobs Classic Publishers.

Eze, G. O. (2008). Issues in Nigeria underdevelopment. Lagos: Vinez Publishers.

Ezema, T. O. (2009). The problems of managing solid waste in a depressed economy. Journal of Sustainable Development, 5(2) 45-55. 
The challenges of waste management to Nigeria sustainable development: A study of Enugu State

Graiser, S. (2007). The best way to manage solid waste in development nations. International Journal of Environment, 4(3) 39-40.

Johnson, W. (2009). Principles of environmental management. London: Routledge.

Laoye, M. E. (1979). Environmental awareness and pollution control. New York: Mcgraw Hills.

Mba, S. O. (2003). Fundamentals of public health for the tropical: Personal and community perspectives. Owerri: Oni Publishers.

Nwokocha, G. (2012). Managing household solid waste. Journal of Policy and Development Studies, 5(1) 29-35.

Okpala, I. C. (2002). Practical guide to environmental auditing, excellence environmental system. Lagos: Vinez Books.

Rogdgers, M. (2011). Fundamentals of development administration. London: S. K. Publishers..

Sanda, L. (2008). The organisational and efficiency of solid waste collection. Toronto: Lexington Books.

Tim, S. R. (2008). The principles of waste management in development nation. International Journal of Policy and Sustainable Development, 5(2) 25-34.

Uche, T. (2010). Public administration in Nigeria. Enugu: HRV Publishers.

Uzoamaka, E. (2010). Principles of personnel management in Nigeria. Enugu: JTC Press. 
Chukwuemeka, E. E. O, Osisioma, B. C., Onwuka, E., \& Ugwu, J. 